\title{
New approaches for identification factors of cost management
}

\author{
Anatolii Kholkin ${ }^{1, *}$ \\ ${ }^{1}$ Vyatka State University, Department of Accounting, Analysis and audit, 610000 Kirov, Russia
}

\begin{abstract}
This article deals with determination and classification factors, that affect the costs and whose changes are result of management decisions. The modern condition of scientific researches in this field of economic science is analyzed. The classification of impact factors is made for machine building industry. Also is given new costs classification according to impact factors. New cost classification includes three classes and eighteen groups of cost. Every class and group is described. The need of this classification for purposes of cost management is defined. Also the practical significance from the use of new costs classification in management decisions and control is described
\end{abstract}

\section{Introduction}

Costs are the most important object of management in each enterprise operating in every branch. Every kind of enterprise attempt to estimate of the optimal level of costs, because it is necessary for survive. The estimation of the optimal level of cost makes by purposeful action on determined factors by made management decisions.

Thus, the amount of costs as the object of management is the result of earlier made decisions on different management levels.

Control of decisions execution is very important for the whole management system. But managers need information that illustrating reflection for decisions affecting to costs factors for making control execution of decisions. For this purpose administration has to understand clearly what kind of decisions or their classes are affecting to costs factors and researches the mechanism of action. Also managers need information about amount of costs variance as result of decisions, that making necessary the new classification or grouping of cost - the classification on impact factors.

For this reason, in this article were discovered the factors, was defined their classification was designed the new grouping of costs. The new grouping of costs is required for identification and evaluation of effects of factors and decisions.

\section{Relevance and scientific significance of problem with brief review of the literature}

The relevance of research topic is dedicated to the existence of following problem: modern methods and procedures of cost management and accounting do not provide the correct measurement of the effect of factors that determining amount of costs that appear as consequences of taken decisions
Also there is no correct definition which factors effect on amount of specific kind or item of cost. It all makes cost management process more complicated, because it is impossible to define clearly what kind of management decisions caused changes of costs and therefore it is impossible to evaluate quantitatively the achievement of expected result of taken and executed decision.

Moreover, different factors have impact on costs with various natures. Therefore, it is more logical to define what kind of costs are affected on specific factors and create on this base the new grouping of costs, as accounting object. This is necessary for requirements setting for forming of the introduced cost grouping in management accounting.

The scientific significance of this article is the reconsideration of previously existing approaches for cost management in the part of quantitative efficiency evaluation of adopted decisions and control of actual parameters of decisions execution. Also, for control purposes the new grouping of cost has been designed. The introduction or this grouping or classification requires modification in using methods of calculation of costs.

Unfortunately, this problem is not enough described in modern scientific literature. Existing problems of cost management were discovered in books of such authors as L.G. Eldenburg, S.K. Wolcott[1],R.W. Hilton, M.W. Maher, F.H. Selto[2],V.G. Lebedev, T.G. Drozdova, B.P. Kustarev[3],L.E. Chertok[4], E.A. Gomonko, T.F. Tarasova[5],A.N. Asaul, V.K. Sevek, C.S. ManchykSat[6]. Existing problems of cost accounting and analysis as information base of cost management were introduced in books of such authors as C. Drury[7], C.T. Horngren[8], S.M. Bragg[9],V.E. Kerimov[10],M.A. Vahrushina[11],G.V. Savitskaya[12].

In most of these books, authors are operating with definition of relevant cost, but they do not designate approaches of determination the dependence between

*Corresponding author: khav76@mail.ru 
specific changed costs and executed decision. Also there are no approaches for comparison of factors impact on costs and made decisions. Authors indicated the volume of production and sales as major factor of cost changes and variations. Thus, modern scientific literature does not contain approaches to the solution to the stated above problem.

\section{Target setting}

The purpose of this article is identification and determination of factors, which affect to production costs in machine building industry, that are changing under executed decisions, that was needed for costs optimization. tasks:

This purpose could be achieved by solving following

- The identification of factors, which affect to amount of costs, the description of the nature of their action,

- Classification and systematization of factors,

- Drafting of factors group and forming costs grouping based on which this factors affect.

And because factors are not the accounting object and only information about the costs are provided in accounting system, which is reasonable to design cost grouping on the basis of impact factors instead of group of factors.

\section{Theoretical aspects of identification of factors and design of costs grouping on the basis of impact factors}

Methods that were used for solution of identified problems are the following: analysis and synthesis, deduction and induction, a thought experiment, classification, grouping and summarizing.

The result of using of these methods was determination the composition of factors, which affect to costs, and conclusion about differences between compositions of factors in various branch. Also, the influence of the factors is different in various branch and enterprise. Therefore in this article defined the factors, which have impact to cost, for machine building enterprise.

All factors separated by the possible impact on them of management on internal and external. Also environmental and ecological factors were separated, and here declared that no one could affect to them.

Internal factors are ones, which administration of enterprise could affect, which could change under management decisions.

External factors are ones, which administration of enterprise or company could not affect, because it depend on decisions were taken on higher management level and these decisions were given to administration through laws and other regulations.

On the base of grouping and classification of factors was designed the new grouping of costs. This grouping or classification includes classes of costs as given below:

1. Costs affected by internal factors:
- Costs depending on construction and technical factors or parameters,

- Costs determined by technological factors,

- Costs depending on the level of used technics,

- Costs determined by organizational factors,

- Costs depending on marketing policy of the company,

- Costs stipulated by ecological policy of enterprise,

- Costs defined by the policy of relationship with suppliers,

- Costs depending on logistic or logistic decisions,

- Costs determined by depreciation policy,

- Costs depended on social policy of company,

- Costs stipulated by accounting and tax policy of enterprise,

- Costs depending on personnel policy.

2. Costs affected by external factors:

- Costs determined by state tax policy,

- Costs depended on governmental social policy,

- Costs stipulated by state technical policy,

- Costs determined by governmental policy in labor relations,

- Costs depending on customs policy.

3. Costs depending on environmental and ecological factors

In addition, it was revealed, that a number of costs are indicated in this grouping could belong to several or different classes or groups, because essentially different decisions could affect to the same article or class of costs.

It is reasonable to describe all classes or groups of cost introduced, and its content was determined approximately.

Costs depending on construction and technical factors or parameters. These are the costs, that are depending on product design, product functions and technical parameters of product so that are the factors that determine usefulness and purpose of goods. This group of costs includes: raw materials costs, auxiliary materials, other materials costs, components and semifinished products, fuel and energy costs, tools and equipment, salary, losses from manufacturing defects, operation costs, package costs, transportation cost.

Product design, product functions and technical parameters set contents of raw materials spent for production of goods. It is because these factors define performance specifications for materials, which spend for production of goods. The effect of this factor for components and semi-finished products is the same.

This factor affects for auxiliary materials costs by determination of ingredients of these materials, which use for given the product certain technical parameters. For example, corrosion resistance.

Also fuel and energy costs depend on this factor, because technical parameters of product and parameters of used material determine requirements for carrying out technological operations, which result is fuel and energy expense. For example, physical parameters of hardening process determined by physical properties of material. Physical parameters of hardening process define fuel and energy expenses. 
This factor makes a decisive influence on choice of tools and equipment and its constructive and technical parameters. It explains the application of modes of technological operations, which has been determined by the composition of raw materials and product design.

Also, salary depends on this factor, because it determines the laboriousness of technological operations. For example, laboriousness of assembly depends on the weight of the product, the complexity of the design and the number of assembly units. All of that define requirements for qualification of personnel and finally for salary.

Losses from manufacturing defects are depending on this factor, because the complexity of product construction increases the probability of defected goods production. Besides of it, if requirements to product and materials become higher the probability of defects detention becomes also higher, because the quality control becomes complicated.

This factor affects to operation and maintenance costs, because it determinates the operating time of equipment, spent for execution of technological operations and technical parameters of the equipment

Similarly, package costs depend on this factor, because construction and technical parameters of product define requirements for packaging materials and time consumption per package.

Also, this factor effect to transportation costs, because it defines requirements to the vehicle, which deliver product and requirements to material handling.

Costs determined by technological factors. These are costs, which depend on selected method operations for manufacturing products and the technological process of manufacturing. This group of costs includes: raw materials costs, auxiliary materials, other materials costs, fuel and energy costs, tools and equipment, salary, operation and maintenance costs. It happens because selected method of operations for products manufacturing affects to quantitative consumption of materials, that determines all material costs. Also, this factor effect to laboriousness of technological operations, that defines salary and operation and maintenance costs.

Costs depending on the level of used technics. These are the costs depending on selected equipment for execution of operations to manufacture of product, its operating or maintenance parameters. This group includes: operation and maintenance costs, repairing costs, because technical parameters of using machinery and equipment determine these costs.

Costs determined by organizational factors. These are the costs depending on the level of organization of labor and production, rationing and control. This group includes: components and semi-finished products costs, energy costs, costs of works and services of production character, tools and equipment, intrafactory moving of cargoes, losses from manufacturing defects, administrative costs and losses from shortages.

Costs depending on marketing policy of the company. These are costs depend on taken decisions in the management of marketing activities of the company.
It includes: advertising costs, package costs, travel expenses.

Costs stipulated by ecological policy of enterprise. These are costs are determined of made decisions in the sphere of ecological management and environmental protection. This group includes: payments for pollution, expenditures on environmental measures.

Costs stipulated by the policy of relationship with suppliers. These costs depend on executed decisions in the field of relationship management with suppliers. It includes all material and transportation costs, because the policy of relationship with suppliers defines prices of purchased materials, terms of delivery and the choice of supplier.

Costs depending on logistic or logistic decisions. These costs are determined executed decisions in logistic. This group includes: transportation costs, intrafactory moving of cargoes costs.

Costs determined by depreciation policy. This group includes sum of fixed assets depreciation, which depend on selected depreciation method.

Costs depending on social policy of company. These costs are determined by made decisions in social policy of company. This group includes: salary, payments for not worked time, compensations and other similar payments.

Costs stipulated by accounting and tax policy of enterprise. These costs depend on selected accounting methods, tax planning and tax accounting methods. It includes: material costs and other cost, which could be taken into account by different method, tax, which are included in costs.

Costs depending on personnel policy. These costs depend on taken decisions in the field of personnel management. It includes: costs of recruitment, costs of personnel teaching and training

Costs determined by state tax policy. These costs depend on tax regulation. This group involves sum of taxes and fees. Also this group includes expenses for tax accounting, which depend on the complexity of the procedure of calculation of taxes and fees.

Costs depending on governmental social policy. These costs determined by legislation in the sphere of social insurance. It includes: compulsory social insurance payments, social insurance benefits, which are paid the employer.

Costs stipulated by state technical policy. These costs are implemented in the field of technical policy and technical regulation based on the requirements of the legislation. This group includes: certification costs, costs of preparation and mastering of production, research and development costs, other similar costs.

Costs determined by governmental policy in labor relations. These costs prescribed by labor legislation. It involves salary in parts of payments for not worked time, compensations and other similar payments, which provided by labor law.

Costs depending on customs policy. These costs determined by customs legislation. It includes: customs duties and taxes, material costs.

Costs depending on environmental and ecological factors. These costs are depended on climate and other 
natural factors. It involves costs of heating and lighting of buildings. In present time, nobody and nothing could to affect to these costs.

\section{Practical significance of the results}

Group of costs and determination of factors were represented in this article allows:

1. Relevant costs could be determined for each managerial decision clearly. Also reflection of costs for specific management action could define.

2. The comprehensive search of reserves of cost reduction could be performed.

3. The effective control of execution decisions in the sphere of cost management could be made.

4. The elimination of costs from effect of external factors could be produced. It is necessary for correct evaluation the contribution of management in cost optimization.

\section{Summary}

The economic situation in our country and in the world, its trends has result that problems of cost optimization in cost management become more and more important. For this purpose factors, which affect to cost, were determined, defined and described. The nature of effect to different costs of these factors was explored. It was estimated by forming of new cost grouping by costs factor. The grouping of costs was designed in this article has not analog in modern economical literature.

Also, possibilities of using of this grouping in costs management practice were described. The usage of new grouping will improve quality and operability of costs management, and it will increase efficiency of activity of company.

\section{References}

1. L.G. Eldenburg, S.K. Wolcott, Cost Management: Measuring, Monitoring, and Motivating Performance (John Wiley and Sons, Ltd, Hoboken, NJ, 2004)

2. R.W. Hilton, M.W. Maher, F.H. Selto, Cost Management: Strategies for Business Decision (Irwin/McGraw-Hill, New York, 2007)

3. V.G. Lebedev, T.G. Drozdova, B.P. Kustarev, Cost management in the enterprise. Textbook for high schools (Piter, St. Petersburg, 2012)

4. L.E. Chertok, Fundamentals of cost management in the enterprise: textbook. (Publisher of SanktPetersburg University of management and economic, St. Petersburg, 2012)

5. E.A. Gomonko, T.F. Tarasova, Cost management in the enterprise (KnoRus, Moscow, 2009)

6. A.N. Asaul, V.K. Sevek, C.S. Manchyk-Sat, Cost management and controlling: textbook (RPD TuvSU, Kyzyl, 2014)
7. C. Drury, Management and Cost Accounting. New Edition (2nd \& Subsequent) (Cengage Learning, Boston, 2012)

8. C.T. Horngren, Srikant M. Datar, Madhav V. Rajan, Cost Accounting: A Managerial Emphasis (Pearson Education Limited, Harlow, 2012)

9. S.M. Bragg, Management Accounting Best Practices: A Guide for the Professional Accountant (Wiley, Hoboken, 2007)

10. V.E. Kerimov, Management accounting: textbook (Dashkov\&Co, Moscow, 2014)

11. M.A. Vahrushina, Management accounting (Omega-L, Moscow,2007)

12. G.V. Savitskaya, A comprehensive analysis of the economic activity of the enterprise: textbook (InfraM, Moscow, 2013) 